\title{
ОБГРУНТУВАННЯ МЕТОДИЧНОЇ СИСТЕМИ НАВЧАННЯ УЧНІВ ПОЧАТКОВОЇ ШКОЛИ ІНТЕГРОВАНОГО КУРСУ «Я ДОСЛІДЖУЮ СВІТ»
}

\author{
Ірина Вікторенко \\ кандидат педагогічних наук, доцент кафедри \\ теорії і практики початкової освіти \\ ДВНЗ «Донбаський державний педагогічний університет» \\ м. Слов'янськ, Україна \\ ORCID ID 0000-0003-3887-4662 \\ viktorenko2210@gmail.com \\ Ірина Федь \\ кандидат педагогічних наук, доцент кафедри \\ теорії і практики початкової освіти \\ ДВНЗ «Донбаський державний педагогічний університет» \\ м. Слов'янськ, Україна \\ irina.e.fed@gmail.com
}

\begin{abstract}
Анотація. У статті теоретично обгрунтовано методичну систему навчання молодших школярів інтегрованого курсу «Я досліджую світ». Автори наголошують на необхідності зміни підходів до освіти на різних іiі рівнях, зокрема на актуальності реалізації компетентнісного, особистісно орієнтованого і діяльнісного підходів та запровадженні інтегрованого навчання. У статті висвітлено зміст поняття «методична система» і розроблено методичну систему навчання інтегрованого курсу «Я досліджую світ», яка $є$ прикладом інтеграції принципово різних галузевих методичних підсистем першого рівня (відповідно до кількості змістових ліній типових освітніх програм Нової української школи), а також інтеграції на рівні опанування змісту конкретних тем, що становить ще один рівень підсистеми.
\end{abstract}

Ключові слова: професійна освіта; природничо-наукова підготовка; інтеграція; методична система; ієрархія.

Постановка проблеми в загальному вигляді. На сучасному етапі розвитку нашої держави дедалі гостріше постає проблема модернізації економіки, оновлення політичної системи, соціальних інститутів та процесів, зокрема освіти на всіх іiі рівнях, завдяки чому Україна повинна стати економічно сильною та впроваджувати інноваційні технології на різних рівнях. Відповідно до Закону України «Про повну загальну середню освіту» (2020), освітній процес у закладах освіти має бути спрямованим «на виявлення та розвиток здібностей та обдарувань особистості, іiі індивідуальних здібностей, досягнення результатів навчання, прогресу в розвитку, зокрема формування і застосування відповідних компетентностей, визначених державними стандартами»; на виході зі школи 
Обгрунтування методичної системи навчання учнів початкової школи інтегрованого курсу «Я досліджую світ»

така особистість умітиме «навчатися впродовж життя, критично мислити, ставити (aмбіmні, aвm.) цілі та досягати їх, працювати в команді, спілкуватися в багатокультурному середовищі» (Концепція Нової української школи, 2016).

Аналіз останніх досліджень і публікацій. Важливим характеристиками випускника середньої загальноосвітньої школи має бути здатність швидко адаптуватися до реальних умов життя в сучасному суспільстві, усвідомлювати $\mathrm{i}$ використовувати свій особистий потенціал для самовираження, самоствердження, самореалізації в особистому та професійному плані, а також в інтересах держави протягом життя. У зв'язку з цим, провідним підходом у Концепції Нової української школи визначено компетентнісний підхід, у якому «зміщується акцент на здатність особи до практичних дій в певному контексті. Звичайний результат навчання «знаю, що...» змінюється у напрямі «знаю як...» (Савченко, 2012, с. 13).

Наголосимо, що компетентнісний підхід насамперед пов’язаний 3 особистісно орієнтованим і діяльнісним підходами до навчання - грунтується на особистості учня, його знаннях, уміннях, потребах, інтересах i може бути реалізованим і перевіреним тільки під час виконання ним самим конкретних дій. Так, у Концепції Нової української школи (2016) наголошено на суб'єктності учіння, необхідності оволодіння учнями способами навчальної діяльності, що сприятиме самостійному освоєнню школярами нових знань та узагальнених способів дій. Відповідно, школяр отримує знання не в готовому вигляді, а здобуває їх сам, усвідомлюючи зміст і способи вираження своєї навчальної діяльності, демонструє право на існування власної думки, відстоює власну точку зору. При цьому функції вчителя, відповідно до Професійного стандарту вчителя початкових класів закладу загальної середньої освіти (2020), набувають партнерського, організаторського, управлінського характеру.

Не менш важливим підходом реформування загальноосвітньої школи є інтеграція, і як похідне - інтегроване навчання. Згідно з думкою О. Лоюк (2019), «актуальність ідеї інтегрованого навчання в тому, що вона є оптимальною для сучасного розвитку національної школи, адже на даному етапі відбувається ускладнення змісту освіти, зростання обсягу необхідної інформації та зменшення часу, відведеного для їі освоєння. Також активного запровадження інтегрованого навчання вимагає потреба подолати протиріччя між розподілом освітнього процесу на окремі предмети, з одного боку, і цілісністю світу та цілісністю сприйняття дитиною довкілля, з іншого» (Лоюк, 2019, с. 188).

I. Бех (2012, с. 5) особливу увагу звертав на те, що сьогодні інтеграція важлива умова сучасної науки і розвитку цивілізації в цілому. Інтеграція 
Обгрунтування методичної системи навчання учнів початкової школи інтегрованого курсу «Я досліджую світ»

розглядається як вимога об'єднання в ціле будь-яких частин чи елементів i вважається необхідним дидактичним засобом, за допомогою якого можна створювати в учнів цілісну картину світу.

Провідна фахівчиня в галузі загальної педагогіки і дидактики початкової школи О. Савченко $(1997$, с. 87$)$ під поняттям «інтеграція» також розуміє «об’єднання, яке направлене на посилення інформаційного змісту і емоційне збагачення сприйняття, мислення i почуттів учнів, завдяки отриманню додаткового цікавого матеріалу, що дає можливість 3 різних сторін пізнати явище, поняття, досягти цілісності знань учнів» (Савченко, 1997, с. 87).

Принципово важлива умова запровадження інтегрованого навчання в освітнє середовище сучасної української школи пов'язана з одним із вагомих наукових відкриттів, яке здійснювалось в останні три десятиліття, «спеціалізація» півкуль головного мозку. Учені з'ясували, що права півкуля, яку умовно називають «художником» (вона найактивніша під час творчої діяльності, сприймання ритму, рими, інтонацій, просторового орієнтування, розпізнавання емоцій, запам'ятовування образів), сприймає та обробляє інформацію $з$ довкілля цілісно, а ліва - послідовно (Воронцова, Пономаренко, 2017).

Тож, оскільки до $6-7$ років (1 - 2 класи) відбувається спеціалізація творчої правої півкулі, актуальним стає питання реформування сучасної освіти задля подолання ізольованого викладання навчальних предметів.

Підсумовуючи вище зазначені аргументи, зауважимо, що виклики часу актуалізували потребу в широкомасштабному перегляді та вдосконаленні освітніх програм, зміні змісту підготовки молодших школярів, підходів до надання освіти. Тож, для реалізації компетентнісного та інтегрованого підходів до навчання в типових освітніх програмах для початкової школи поміж інших запроваджено інтегрований курс «Я досліджую світ», ключовими ідеями якого $\epsilon$ :

повна або часткова інтеграція кількох освітніх галузей (природничої, громадянської та історичної, соціальної і здоров'язбережувальної, технологічної, інформатичної, мовно-літературної (частково), математичної (частково));

спрямованість на розвиток множинних компетентностей (предметних компетентностей, визначених Державним стандартом і типовими освітніми програмами; психосоціальних компетентностей, визначених переліком ЮНІСЕФ і ЮНЕСКО; кЛючових компетентностей з переліку СС; множинного інтелекту (7 із 8 видів інтелекту за Г. Гарднером); уміння вчитися);

запровадження інтерактивних методів навчання на ситуаціях, максимально наближених до реального життя, що $є$ вкрай важливим для 
Обгрунтування методичної системи навчання учнів початкової школи інтегрованого курсу «Я досліджую світ»

здоров’я, безпеки, соціалізації та самореалізації особистості молодшого школяра;

- спеціальна підготовка вчителів, їхньої ерудованості і високого професіоналізму.

Останнє, зокрема, зумовило потребу в розробці методичних систем, новітніх технологій, інтенсифікації впровадження в навчальний процес форм та ефективних методів організації успішного освітнього середовища відповідно до вимог сьогодення. Методичні системи навчання учнів у загальноосвітній школі i взаємозалежність методів навчання в їх межах досліджували вітчизняні та зарубіжні вчені: Т. Байбара (методична система навчання природознавства), Л. Іжойкіна, Л. Орлова (модель методичної системи формування самоконтролю та самооцінки навчальних дій школярів у процесі навчання природознавства), Н. Котелянець (методична система трудового навчання), О. Кучерук (методична система навчання української мови), М. Мартинюк (методична система навчання фізики в основній школі), С. Скворцова (методична система навчання учнів початкових класів розв'язування математичних задач), Я. Пасічник (методична система формування обчислювальних навичок молодших школярів), О. Чашечникова (методична система навчання математики молодших школярів), Н. Шиліна (методична система формування елементарних геометричних уявлень) та ін..

Не зважаючи на те, що проблема побудови моделі методичної системи навчання інтегрованого курсу «Я досліджую світ» ще не була предметом окремого дослідження у вітчизняній науці, аналіз наукових джерел свідчить про зростаючий інтерес до окремих елементів цього питання: О. Анаєвої, I. Андрусенко, В. Винниченка, Н. Котелянець (реалізація змісту інтегрованого курсу «Я досліджую світ» в умовах НУШ), Н. Бібік (навчально-методичний комплект з курсу «Я досліджую світ» у вимірах компетентнісно орієнтованого навчання), Т. Васютіної, І. Іщук, В. Остроухової (атлас з природознавства як засіб навчання), М. Єпіхіної (особливості викладання інтегрованого курсу «Я досліджую світ» у Новій українській школі в контексті педагогіки партнерства), В. Партоли, Н. Смолянюк (використання методу проектів у процесі викладання інтегрованого курсу «Я досліджую світ»), О. Сорочинської (інноваційні форми навчання як засіб екологічного виховання молодших школярів на уроках інтегрованого курсу «Я досліджую світ») та ін.

Формулювання цілей статті (постановка завдання). Мета дослідження полягає в теоретичному обгрунтуванні методичної системи навчання інтегрованого курсу «Я досліджую світ», адекватної новій редакції Державного

Професіоналізм педагога: теоретичні й методичні аспекти. - Вип. 14 (Ч. 1). - Слов’янськ, 2021. 
Обгрунтування методичної системи навчання учнів початкової школи інтегрованого курсу «Я досліджую світ»

стандарту початкової загальної освіти, вимогам сучасного етапу розвитку освіти та новим сучасним цілям загальної природничо-наукової освіти.

Результати дослідження. Аналіз зарубіжних та вітчизняних літературних джерел дозволяє стверджувати, що навчання дисциплін природничого спрямування («Оточуючий світ» (Фінляндія), «Батьківщина та навколишній світ» (Германія), «Природознавство» і «Я і світ» (Польща), Science (Канада), «Наука» (Нідерланди) та ін. є частиною загальної освіти і входять до переліку обов'язкових предметів. Особливу увагу слід звернути на те, що у всіх країнах природничі науки об'єднані в один інтегрований предмет як результат «вплітання інтегративних ниток» (Бенджамін Блум) до навчального плану, щоб сприяти зв'язкам між предметними областями; сьогодні інтегроване навчання $\epsilon$ абсолютно звичним.

Із першого вересня 2017- 2018 року молодші українські школярі почали опановувати інтегрований курс під назвою «Я досліджую світ», який поєднує навчальний зміст відразу кількох освітніх галузей: за типовою програмою НУШ 1 таких галузей три (природнича, громадянська та історична, соціальна та здоров'язбережувальна), за типовою освітньою програмою НУШ 2 таких галузей сім (мовно-літературна, математична, природнича, технологічна, громадянська та історична, соціальна та здоров'язбережувальна, інформативна).

Слід зауважити, що основною освітньою галуззю в інтегрованому курсі «Я досліджую світ» визначено природничу освітню галузь, яка гармонійно інтегрується майже з усіма освітніми галузями, визначеними в Державному стандарті початкової освіти, «бо природа $є$ одним із найцінніших чинників розумового, патріотичного, трудового, естетичного розвитку особистості дитини та володіє великими можливостями для розвитку пізнавальних інтересів молодших школярів. Це зумовлено тим, що його вивчення грунтується на безпосередніх дитячих спостереженнях за навколишніми явищами та об'єктами природи, елементарних дослідженнях які проводять учні» (Епіхіна, 2019, с. 68); природознавство $є$ основою ії предметного наповнення.

Наразі гостро стоїть проблема методичної підготовки «нової генерації педагогічних кадрів початкової ланки освіти, готових до конструювання навчально-пізнавальної діяльності молодших школярів на засадах концепції компетентнісно орієнтованої освіти як одного із дієвих шляхів іiі реформування та удосконалення якості» (Вікторенко, Гончаровара, 2019, с. 53).

Як наслідок реформування загальної середньої освіти «Нова українська школа» актуалізувалась потреба модернізації вищої педагогічної освіти. До навчального плану підготовки здобувачів першого (бакалаврського) рівня вищої 
Обгрунтування методичної системи навчання учнів початкової школи інтегрованого курсу «Я досліджую світ»

освіти спеціальності 013 Початкова освіта за освітньо-професійною програмою Початкова освіта було внесено нормативну навчальну дисципліну фахового (професійно-практичного) циклу «Методика навчання інтегрованого курсу «Я досліджую світ». Цей освітній компонент являє собою методичну систему, що має на меті формування предметно-методичної компетентності майбутнього вчителя початкової школи щодо викладання інтегрованого курсу «Я досліджую світ», зокрема, його готовності та спрямованості на всебічний розвиток дитини, iii талантів, здібностей, компетентностей та наскрізних умінь відповідно до вікових та індивідуальних психофізіологічних особливостей і потреб на основі формування цілісного образу світу в процесі засвоєння різних видів соціального досвіду, який охоплює систему інтегрованих знань про природу і суспільство, ціннісні орієнтації в різних сферах життєдіяльності та соціальної практики, способи дослідницької поведінки, що забезпечують їхню готовність до життя в демократичному й інформаційному суспільстві (Вікторенко, Гончаровара, 2019). Відповідно до рекомендацій за результатами дослідження впровадження реформи «Нова українська школа» майбутні вчителі мають бути забезпечені методиками, що формують такий тип взаємодії з учнями як співпраця. Учителі повинні вміти спонукати до командної роботи, нагороджувати і заохочувати, приймати пропозиції та ідеї, спонукати до самостійного пошуку рішень, дискутувати та розмовляти тощо.

Реалізація мети дослідження потребує подальших розвідок у з'ясуванні сутності поняття «методична система».

Як уже було зазначено, у працях наших попередників не було спроб розробити та теоретично обгрунтувати методичну систему навчання інтегрованого курсу «Я досліджую світ». У тлумачному словнику поняття «система» трактують як порядок, зумовлений правильним, планомірним розташуванням і взаємним зв'язком частин чого-небудь; продуманий план; заведений, прийнятий порядок; сукупність принципів, що є основою певного вчення; сукупність методів, прийомів здійснення чого-небудь (Великий тлумачний словник сучасної української мови, 2007, с. 1320-1321).

I. Коваленко, П. Бідюк, О. Гожий (2004) зазначають, що система - це сукупність елементів, певним чином пов'язаних і взаємодіючих між собою для виконання заданих цільових функцій. О. Кучерук (2011) розглядає сутність поняття «методична система навчання» як комплекс взаємопов'язаних цілей, принципів, змісту, методів, засобів, організаційних форм навчання, що на основі взаємодії викладача й студентів забезпечує прогнозований позитивний результат.

Професіоналізм педагога: теоретичні й методичні аспекти. - Вип. 14 (Ч. 1). - Слов’янськ, 2021. 
За потрактуванням В. Плахотника (2010), методична система - це сукупність спеціально організованих засобів навчання, яка на основі відібраного змісту навчального предмета у взаємодії з найближчим середовищем сприяє досягненню навчальних цілей. Під засобами навчання В. Плахотник (2010) розуміє сукупність предметів, явищ, способів дій, ідей і закономірностей, за допомогою яких досягаються цілі навчально-виховного процесу; найближче середовище становлять викладач i студенти (близьке середовище - це навчальний заклад, віддалене середовище - суспільство). Методична система може функціонувати завдяки входам i виходам, через які реалізується взаємозв'язок між системою і найближчим середовищем: через виходи системи надходить інформація про те, як необхідно навчати і як учитися, про результати процесу навчання та функціонування системи; через входи дослідник вносить корективи щодо вдосконалення методичної системи або іiі підсистем, коли в цьому виникає потреба.

Результати наукового пошуку дали можливість констатувати, що методична система складається 3 тих же компонентів, що й педагогічна та дидактична система (мета, зміст, методи, форми та засоби). За потрактуванням Н. Грицай (2015), «система методичної підготовки майбутніх учителів» - це сукупність взаємопов'язаних компонентів підготовки студентів у вищому навчальному закладі, спрямованих на формування методичної готовності майбутніх педагогів до виконання професійної діяльності в контексті вивчення дисципліни. Структурними компонентами системи методичної підготовки авторкою визначено такі: мета (системотвірний компонент, від якого залежать всі інші компоненти); зміст (базова дисципліна); технології: форми, методи й засоби навчання (інтерактивні технології, технології контекстного, проектного навчання, портфоліо, мультимедійні технології та ін.); результати підготовки (рівні методичної готовності, індивідуальний методичний стиль, авторська методична система (Грицай, 2015).

У руслі вище викладених ідей актуалізації зазнає погляд І. Смагіна (2013) на принципову відмінність технології від методичної системи. Вона полягає в «неможливості зміни алгоритму, відступу від змістових і процесуальних складових у межах технології», оскільки будь-яка технологія, за переконаннями науковця (узявши до уваги найбільш поширені словникові визначення змісту поняття), - це алгоритмізована послідовність дій (організаційних заходів, операцій, прийомів, режимів) для отримання прогнозованого результату 3 номінальною якістю й оптимальними витратами (Смагін, 2013, с. 42). Отже, алгоритмізованість та сувору послідовність елементів І. Смагін (2013) пропонує

() ДВНЗ «Донбаський державний педагогічний університет» 
Обгрунтування методичної системи навчання учнів початкової школи інтегрованого курсу «Я досліджую світ»

вважати основними критеріями для розмежування змісту досліджуваних дефініцій: «На нашу думку, використання поняття «педагогічна технологія» в методичній царині допустиме, коли мова йде про використання в навчанні ТЗН, або про системну сукупність прийомів і правил навчальної роботи у певній послідовності, наприклад, технологія критичного мислення, технологія ділової гри, дебатна технологія тощо. У всіх інших випадках не варто забувати традиційне для предметних методик навчання поняття «методична система» (Смагін, 2013, с. 44).

Разом із тим, досліджуючи особливості методичної системи, I. Смагін (2013) звертає увагу на те, що вони можуть відтворюватися; спрямовуються і на змістову i на процесуальну сторону навчання, а головне - варіабельно враховують стан суб'єкта навчання - дітей. Тому, з «позицій аналогії методичної системи ...конспект уроку, написаний відповідно до вимог Державного стандарту і навчальної програми, по-різному реалізується в різних класах, 3 урахуванням їх особливостей (Смагін, 2013, с. 44).

Ці та інші вище означені аспекти лежать в основі розуміння сутності та проєктування досліджуваного феномену. Тож, методична система навчання інтегрованого курсу «Я досліджую світ» є прикладом інтеграції принципово різних галузевих методичних підсистем першого рівня (умовно позначимо ГМПС «МОВ», ГМПС «МАО» та ін.; у лапках наводимо скорочення, яке використовуються в індексі державних вимог до обов'язкових результатів навчання); відповідно до типової програми НУШ-1 (О. Савченко) таких методичних підсистем буде три: МПС «ПРО»- природнича, МПС «ГІО»громадянська та історична, МПС «СЗО» - соціальна та здоров'язбережувальна за типовою програмою НУШ-2 Р. Шиян) - 7: МПС «МОВ»- мовно-літературна, МПС «МАО» - математична, МПС «ПРО» - природнича, МПС «ТЕО»технологічна, МПС «ГІО»- громадянська та історична, МПС «СЗО»- соціальна та здоров'язбережувальна, МПС «ІФО» - інформатична.

Кожна зазначена методична підсистема містить у собі МПС нижчого, другого рівня - навчання змістових ліній (МПС-3М1, МПС-3М2, МПС-3Mn). Кількість методичних підсистем нижчого, другого, рівня залежить від:

1) типової програми: кожна програма відповідно до Закону України «Про освіту» та Державного стандарту початкової освіти має свою мету, коротко вказано відповідний зміст кожного навчального предмета чи інтегрованого курсу, пропоновано форми організації освітнього процесу та загальні результати навчання здобувачів освіти в цілому. За ними впорядковано обов'язкові 
Обгрунтування методичної системи навчання учнів початкової школи інтегрованого курсу «Я досліджую світ»

результати навчання здобувачів освіти, які $\epsilon$ основою для їх подальшого навчання на наступних рівнях загальної середньої освіти;

2) освітньої галузі: у кожній галузі відповідно до зазначених мети i завдань виокремлено специфічні для дисципліни змістові лінії, які теж мають певні дидактичні цілі і підцілі, пропонується зміст та очікувані результати навчання здобувачів освіти.

Кожна змістова лінія як методична підсистема нижчого рівня є засадовою для утворення методичних підсистем ще нижчого - третього рівня - на рівні опанування змісту конктретних тем. Методика формування загальних умінь, передбачених змістовими лініями, які охоплюють складники названих вище галузей в їх інтегрованій суті, реалізується через методичні системи навчання конкретних тем (МПС-Т1, МПС-Т2, МПС-Tn), які у свою чергу мають певну мету, зміст, форми, методи і засоби формування окремих умінь, а, отже, організують методичну підсистему навчання.

Не вдаючись до детального розгляду функціонування досліджуваної методичної системи, слід відзначити певну ієрархічну залежність між іi структурантами - методичною системою і їі підсистемами: МС навчання «ЯДС» - галузева МПС - МПС змістових модулів - МПС навчання конкретних тем; при чому, кожна первинна методична система є системотвірною для наступної.

\section{Висновки $з$ дослідження і перспективи подальших розвідок у цьому} напрямі. Виклики часу зумовили актуалізацію потреби в перегляді та вдосконаленні освітніх програм на різних рівнях освіти, зміні змісту підготовки учнів початкової школи, підходів до організації освіти. Реалізація компетентнісного та інтегрованого підходів до навчання, визначених в типових освітніх програмах для початкової школи, сприяла запровадженю інтегрованого курсу «Я досліджую світ», спрямованого на інтеграцію кількох освітніх галузей, розвиток множинних компетентностей; запровадження інтерактивних методів навчання в ситуаціях, максимально наближених до реального життя; спеціальну підготовку вчителів, розвиток їхнього високого професіоналізму. Це зумовлює спрямування наукових розвідок на розроблення методичної системи навчання інтегрованого курсу «Я досліджую світ», яка б задовольняла вимогам нової редакції Державного стандарту початкової загальної освіти, сучасного етапу розвитку освіти та новим цілям загальної природничо-наукової освіти.

Вважаємо, що методична система навчання курсу «Я досліджую світ» являє собою ієрархічну залежність структурантів - власне методичної системи та ii підсистемам: методична система навчання курсу «ЯДС» - галузева методична підсистема - методична підсистема змістових модулів - методична 
I. ВІКТОРЕНКО, І. ФЕДЬ

Обгрунтування методичної системи навчання учнів початкової школи інтегрованого курсу «Я досліджую світ»

підсистема навчання конкретних тем, де кожна первинна методична система $є$ системотвірною для наступної.

\section{СПИСОК ВИКОРИСТАНИХ ДЖЕРЕЛ}

1. Бех, І. (2012). Інтеграція як освітня перспектива. Початкова школа, 5, 5-6.

2. Великий тлумачний словник сучасної української мови. (2007). Уклад. і голов. ред. В.Т. Бусел. Ірпінь: ВТФ «Перун»,.

3. Вікторенко, I., Гончаровара, Н. (2019). Підготовка майбутніх учителів до оновлення змісту освіти в умовах реформування Нової української школи (на прикладі методики навчання інтегрованого курсу «Я досліджую світ»). Інноваџійна педагогіка, Спецвипуск, 52-56.

4. Воронцова, Т.В., Пономаренко, В.С. (2017). Вчимося жити разом. Посібник для вчителя з розвитку сочіальних навичок у курсі «Основи здоров'я» (початкова школа). Київ: Видавництво «Алатон».

5. Грицай, Н.Б. (2015). Структурні компоненти системи методичної підготовки майбутніх учителів біології. Science and Education a New Dimension. Pedagogy and Psychology, III (21), Issue: 43.

6. Епіхіна, М.А. (2019). Особливості викладання інтегрованого курсу «Я досліджую світ» у Новій українській школі в контексті педагогіки партнерства. Науковий вісник Ужгородського університету. Серія: «Педагогіка. Соціальна робота», 1 (44), 67 - 70.

7. Закон України «Про повну загальну середню освіту (Із змінами, внесеними згідно із Законом № 764-IX від 13.07.2020). URL: https://zakon.rada.gov.ua/laws/show/463-20\#Text.

8. Коваленко, І.І., Бідюк, П.І., Гожий, О.П. (2004). Вступ до системного аналізу. Миколаїв : МДГУ ім. Петра Могили.

9. Концепція «Нова украӥнська школа». (2016, 27 жовтня). URL: https://mon.gov.ua/storage/app/media/zagalna\%20serednya/novaukrainska-shkola-compressed.pdf

10. Кучерук, О.А. (2011). Система методів навчання украӥнської мови в основній школі: теорія і практика. Житомир: Вид-во ЖДУ імені І. Франка.

11. Лоюк, О.В. (2019). Інтегроване навчання як складова реалізації ідей нової української школи. Управління в освіті : Матеріали IX Міжнародної науково-практичної конференції (Львів, 4-5 квітня 2019 року); за заг. ред. Ю.М. Козловського. Львів: Видавництво «Левада», 187-189.

12. Наказ Міністерства розвитку економіки, торгівлі та сільського господарства України № 2736 від 23.12.2020 р. «Про затвердження професійного стандарту за професіями «Вчитель початкових класів закладу загальної середньої освіти», «Вчитель закладу загальної середньої освіти», «Вчитель 3 початкової освіти (з дипломом молодшого спеціаліста)». URL: https://zakon.rada.gov.ua/rada/show/v2736915-20\#Text

13. Плахотник, В. (2010). Інтеграція методичної системи в загальну теорію систем. Українська мова і література в школі, 8, 66-69.

14. Савченко, О. (2014). Упровадження компетентнісного підходу в початкову освіту: здобутки і нерозв'язані проблеми. Рідна школа, 4-5, 12-16

15. Савченко, О. (1997). Сучасний урок у початкових класах. Київ : Магістр-S.

16. Смагін, I.I. (2013). Педагогічна технологія і методична система в шкільному навчанні. Вісник Житомирського державного університету імені Івана Франка, 1, 40-43

\section{SUBSTANTIATION OF THE METHODOLOGICAL SYSTEM OF TEACHING PRIMARY SCHOOLCHILDREN OF THE INTEGRATED COURSE "I EXPLORE THE WORLD"}

Професіоналізм педагога: теоретичні й методичні аспекти. - Вип. 14 (Ч. 1). - Слов’янськ, 2021. 
I. ВІКТОРЕНКО, І. ФЕДЬ

Обгрунтування методичної системи навчання учнів початкової школи інтегрованого курсу «Я досліджую світ»

Iryna Viktorenko

Candidate of Pedagogical Sciences, Associate Professor of Primary

Education Theory and Practice Department

SHEI "Donbas State Pedagogical University"

Sloviansk, Ukraine

ORCID ID 0000-0003-3887-4662

viktorenko2210@gmail.com

\author{
Iryna Fed \\ Candidate of Pedagogical Sciences, Associate Professor of Primary \\ Education Theory and Practice Department \\ SHEI "Donbas State Pedagogical University" \\ Sloviansk, Ukraine \\ irina.e.fed@gmail.com
}

\begin{abstract}
The article theoretically substantiates the methodological system of teaching junior schoolchildren the integrated course "I explore the world". The challenges of the time led to the actualization of the need to review and improve educational programs at different levels of education, change the content of training primary school students, approaches to the organization of education.

The implementation of competency and integrated approaches to learning, defined in the typical educational programs for primary school, contributed to the introduction of an integrated course "I explore the world", aimed at integrating several educational areas, the development of multiple competencies; introduction of interactive teaching methods in situations as close as possible to real life; special training of teachers, development of their high professionalism. The authors emphasize the need to change approaches to education at its various levels, in particular the relevance of the implementation of competency, personality-oriented and activity-based approaches and the introduction of integrated learning. The article highlights the concept of "methodological system" and defines it as a set of interrelated components of student training in higher education, aimed at forming the methodological readiness of future teachers to perform professional activities in the context of studying the discipline.

The authors develop a methodological system of teaching an integrated course "I explore the world", which is an example of integration of fundamentally different sectoral methodological subsystems of the first level (according to the number of content lines of typical educational programs of the New Ukrainian School), and at the level of mastering the content of the specific topics, which is another level of the subsystem.
\end{abstract}

Key words: professional education; natural science training; integration; methodological system; hierarchy.

\title{
REFERENCES
}

1. Bekh, I. (2012). Integration as an educational perspective. Primary School, 5, 5-6.

2. Large explanatory dictionary of the modern Ukrainian language. (2007). Str. and eds. V.T. Busel. Irpin: "Perun".

3. Viktorenko, I., Honcharovara, N. (2019). Preparation of future teachers for updating the content of education in the context of reforming the New Ukrainian School (on the example of teaching methods of the integrated course "I explore the world"). Innovative pedagogy, Special issue, $52-56$.

4. Vorontsova, T.V., Ponomarenko, V.S. (2017). We learn to live together. A teacher's 


\section{I. ВІКТОРЕНКО, І. ФЕДЬ}

Обгрунтування методичної системи навчання учнів початкової школи інтегрованого курсу «Я досліджую світ»

guide to social skills in the Basics of Health course (primary school). Kyiv: Alaton Publishing House.

5. Hrytsai, N.B. (2015). Structural components of the system of methodical training of future biology teachers. Science and Education a New Dimension. Pedagogy and Psychology, III (21), Issue: 43.

6. Epikhina, M.A. (2019). Features of teaching the integrated course "I explore the world" in the New Ukrainian School in the context of partnership pedagogy. Scientific Bulletin of Uzhhorod University. Series: "Pedagogy. Social work", 1 (44), 67-70.

7. Law of Ukraine "On Complete General Secondary Education" (As amended in accordance with Law № 764-IX of July 13, 2020). URL: https://zakon.rada.gov.ua/laws/show/46320\#Text.

8. Kovalenko, I.I., Bidiuk, P.I., Gozhiy, O.P. (2004). Introduction to systems analysis. Mykolaiv: Mykolaiv State University named after Petra Mogili.

9. The Concept of "New Ukrainian School". (October 27, 2016). URL: https://mon.gov.ua/storage/app/media/zagalna\%20serednya/novaukrainska-shkola-compressed.pdf

10. Kucheruk, O.A. (2011). The system of methods of teaching the Ukrainian language in primary school: theory and practice. Zhytomyr: Ivan Franko State University Publishing House.

11. Loiuk, O.V. (2019). Integrated learning as a component of realization of ideas of the new Ukrainian school. Management of Education: Proceedings of the IX International Scientific and Practical Conference (Lviv, April 4-5, 2019); for general ed. Yu.M. Kozlovsky. Lviv: Levada Publishing House, 187-189.

12. Order of the Ministry of Economy, Trade and Agriculture of Ukraine № 2736 of 23.12.2020 "On approval of the professional standard for the professions "Primary school teacher of general secondary education", "Teacher of general secondary education", "Primary teacher (with a diploma of a junior specialist)". URL: https://zakon.rada.gov.ua/rada/show/v2736915-20\#Text

13. Plakhotnik, V. (2010). Integration of methodical system into general systems theory. Ukrainian language and literature at school, 8, 66-69.

14. Savchenko, O. (2014). Introducing a competency-based approach to primary education: achievements and unresolved issues. Native school, 4-5, 12-16

15. Savchenko, O. (1997). The modern lesson in primary school. Kyiv: Master-S.

16. Smahin, I.I. (2013). Pedagogical technology and methodical system in school education. Bulletin of Zhytomyr State University named after Ivan Franko, 1, 40-43.

Матеріали надійшли до редакції 14.03.2021 p.

Професіоналізм педагога: теоретичні й методичні аспекти. - Вип. 14 (Ч. 1). - Слов’янськ, 2021. 